\title{
Introduction
}

\section{The Politics of Violence against Women}

In the early summer of 2012, another case of sexual abuse reached Afghan television screens and the international press. Lal Bibi, an eighteen-year-old nomad woman from the province of Kunduz, came forward in Afghan media recounting how, on May 17, 2012, she was seized by men linked to a local armed group. She was held captive for five days and sexually assaulted as revenge for her cousin's elopement with a woman from the family of one of the kidnappers. Lal Bibis family declared to journalists that unless justice was done, they would have no option but to kill her. However, Afghanistan's women's right activists quickly mobilized in support, and pressure mounted on the government to arrest the perpetrators.

But back in Kunduz, the man accused of the rape protested that no such thing had taken place. He argued that there had been an agreement of baad-a practice in which a woman or girl is given in marriage as a form of compensation for a crime or an affront. A mullah had married Lal Bibi to him just before intercourse, and "once the marriage contract is done, any sexual intercourse is not considered rape" (A. J. Rubin 2012). In present-day Afghanistan, this version of events did not necessarily exonerate him from having committed a crime. Women's rights activists pointed out that forced marriage was also an offense, according to Afghan law and particularly the new Elimination of Violence against Women law (EVAW law), which had become a cornerstone of gender activism in the country. Moreover, his attempt to justify his actions with reference to a framework of baad implicated others. A friend of mine, who happened to be in Kunduz on fieldwork at the time, told me upon his return that the elders who had sanctioned the kidnapping (as an appropriate redress for the affront to the honor of the eloped girl's father) 
now found themselves being investigated for crimes against the EVAW law on the grounds that they had facilitated a baad.

Lal Bibi was one of several Afghan women and girls who have appeared in national media in recent years with harrowing stories of sexual abuse, accompanied by relatives demanding justice from the Afghan government. Yet the role of the government, as well as other powers, in intervening in abuses against women was fiercely contested during the first fifteen years following the United States-led overthrow of the Taliban in 2001. The questions of whether, to what extent, and how central authorities should intervene in different forms of gender violenceand the very questions of what exactly constituted violations and who was the violated party-were matters that went to the core of Afghan society. How was rape to be understood-as a crime against the woman herself or primarily as an affront against her family? Was "forced marriage" a crime, or should parents (particularly fathers) be left in peace to arrange their daughters' marriages as they saw fit? Could adulterous women call upon the protection of the state? Was beating disobedient wives the prerogative of husbands or something that the government should jail men for? The answers to questions such as these had-and continue to have-great implications for women's lives in Afghanistan. But there were also other issues at stake-where to draw the boundaries between private and public domains; which and whose notions of justice, rights, and obligations should prevail; and, ultimately, how the answers to these questions affected competing claims to exercise supreme political power in the country.

The terrain on which these battles were fought out was extraordinarily fluid and fragmented. A beleaguered group of women's rights activists in the capital, many of them recently returned from exile, made tenuous alliances with parts of the international donor community, but this turned out to be a difficult balancing act between concessions to conservative adversaries and dependence on external actors. An alliance of women's rights activists, personnel from foreign embassies, and progressive justice officials succeeded in getting the new EVAW law promulgated. But the process revealed bitter divisions within women's groups and difficulty in gaining wider acceptance for their ideas. It also exposed their dependence on a friendly executive branch and a degree of isolation from broader political constituencies. In courts and prosecution offices, some officials refused to apply the EVAW law altogether, saying that its legal status was unclear-the law had been passed as a presidential decree and had not been approved in Parliament. At the same time, Western aid donors made the implementation of the EVAW law a central condition for aid disbursements, and a massive internationally supported apparatus was mobilized to disseminate and enforce the law.

The unpredictability produced by these competing legal regimes was acutely felt by numerous women and girls who fled unwanted marriages or family abuse and sought the assistance of the courts and the protection of shelters. These institutions 
were a testing ground for what kind of gender relations would be officially sanctioned. In some cases, they upheld women's claims. On many other occasions, however, they sided with the families' counterclaims, sending the women back to their families or even to jail, which signaled that public regulation in this domain would reinforce kinship and conjugal claims over women rather than support a transformation that granted women full legal personhood. Meanwhile, the shelters housing many of the "runaway" women faced a conservative backlash, stirred up by media campaigns that drew upon popular discontent with a prolonged and dysfunctional Western intervention and denounced the shelters as a foreign implant.

Even the outrage surrounding rape cases like Lal Bibi's contained ambiguous agendas. To many people, the popular demand for state intervention in cases of rape was a significant shift that signaled support for women's rights over family privacy. However, a closer look at the campaigns for justice suggested that they were driven by many different concerns, some of which had little to do with women's rights. In other words, whether this new "openness" surrounding rape would constitute progress for women was, like many aspects of gender violence in post2001 Afghanistan, still an open question.

These contestations are at the center of this book. I explore the struggles over the meaning of violence against women during the first fifteen years of the postTaliban order in Afghanistan and their implications for gender and power. The rest of the introduction lays out the analytical departure points of the book. I start by showing how definitions of violence against women in a given context serve as windows into gender relations and how the construction of certain abuses against women as private-and therefore beyond the law and political interventionestablishes a hierarchical gendered relationship in which women are placed under the sovereign power of male family members. I then argue that attempts to define and govern gender violence also illuminate broader fields of power, such as the regulatory power of the state. However, I suggest that the separate, discreet units of analysis in much of the literature on gender and governance-whether "the state," "the global," or "the tribal" - is misleading in the Afghan case. Instead, I present transnational assemblages of rule as a more useful concept to capture the forms of power at work in contemporary Afghanistan. The final sections of the introduction provide the reader with an account of methodological choices and fieldwork trajectories and finally a discussion of some of the ethical pitfalls of doing research in post-2001 Afghanistan.

\section{VIOLENCE AGAINST WOMEN AS ANALYTICAL ENTRY POINTS}

This book is filled with people who sought in various ways to have their ideas about gender violence accepted by others. For some it was a matter of immediacy. 
Young women would stand before a judge hoping to avoid a jail sentence-or even execution-by asserting that what had happened to them was rape or that they had acted within the limits of the law when escaping with a man or from an unwanted marriage. Grandmothers would make anxious calls to the local police, trying to convince them that they should arrest a runaway granddaughter. Fathers would look into a television camera, demanding to know where the honor of the country's leaders had gone, since they were incapable of stopping the violation of schoolgirls. Other men would defend their right to conduct a marriage without the consent of the bride's family, and yet others their right to kill a rebellious niece or to be compensated for a runaway wife.

For some of the people in this book, the issue of gender violence was a question of principle rather than personal circumstance. In order to convince their colleagues that wife beating should be a punishable crime, some members of Parliament urged a less literalist interpretation of the Quran, while their opponents countered with warnings against the implications of straying away from the holy scriptures. As controversies over women's shelters peaked, a journalist convinced of the self-serving ways of the NGO women who ran the shelters would attempt to discredit shelter residents as dangerous seductresses. Some shelter managers, in order to ensure their institutions' independence from the government, appealed to Western fears of the Taliban, depicting a government takeover of the shelters as a first step toward conceding defeat to terrorism.

The structuring theme of this book is that whatever acts people consider or call violence (khoshonat in Dari, the Afghan dialect of Farsi) is always specific to and situated within a particular context. Violence, in English and in many other languages, connotes transgression and illegitimacy. Describing something as an act of violence suggests that it is a threat to the social, sexual, and political order and that it must be stopped, punished, or avenged. On the other hand, the nonrecognition of violent acts renders them unproblematic-or even, in some cases, necessarythereby permitting or sanctioning their continuation. Naming violence is therefore invested with great political importance, and it follows that categorizations of violence are not fixed; they are sites of contestation (Merry 2009).

Applied specifically to gender, this perspective means that delineations or definitions of violence against women in a given historical context are entry points to the gender relations in that context. Feminist analysis has long pointed out how the construction of a private/public dichotomy in which certain abuses against women are considered private (and therefore beyond the law and political intervention) in effect establishes a hierarchical gendered relationship (Schneider 1991). I propose that the concept of sovereignty is useful for appreciating this relationship. As Comaroff and Comaroff write, "We take the word sovereignty to connote the more or less effective claims on the part of any agent, community, cadre or collectivity to exercise autonomous, exclusive control over the lives, deaths, and 
conditions of existence of those who fall within a given purview, and to extend over them the jurisdiction of some kind of law" (2006: 35).

When violence and even murder of women at the hands of their husband or family are considered permissible, women are effectively placed under their sovereignty, rather than under the sovereignty of public authorities, such as the state. In this sense, a form of what Humphrey calls a "localized sovereignty, nested within higher sovereignties" but "nevertheless retaining a domain within which control over life and death is operational" is granted to the household head (2004: 420). The feminist analysis and activism aimed at making violence against women a public issue have thereby been mounting a challenge to the sovereign claim of families over women. Indeed, the very act of naming an act as a violation against someone other than the family sovereign signifies a challenge to absolute sovereignty, as it names other people as holders, or partial holders, of rights. This is also the case with violations carried out by people outside the family. The framing of sexual violence as an offense against a woman, as opposed to an offense against her husband or father, constitutes women as legal persons to whom other sovereigns hold obligations, and it potentially signifies a radical transformation of gender relations. As we shall see, the contestations over gender violence taking place in Afghanistan embodied these competing claims of sovereignty at their heart. Families claimed sovereign rights over women-to preside over their marriage and sexuality and to sanction insubordination, sometimes through violent means. Counterclaims asserted women's autonomous status and their right to make independent decisions and to make claims of damage against their own families or against others.

At this point in the discussion, however, it seems necessary to deal with the fact that the term violence against women carries a historical baggage of its own. Since it moved to the center of transnational women's activism in the early 1990s, violence against women (VAW) has become an established term and a particular discursive frame underpinning a global apparatus of action, intervention, and regulation. The emergence of VAW as an established phrase happened after feminist activists around the world-who had set up shelters, counseling centers, and treatment programs for batterers (Merry 2009: 76) and launched antirape campaigns-formed an international campaign to have violence against women defined as a human rights violation. Their demand proved phenomenally successful. It resulted in a series of U.N. resolutions and declarations, the creation of a special rapporteur on violence against women, the enumeration of certain kinds of sexual violence as serious crimes in international law, and the articulation of the principle of due diligence, which went some way in making states accountable for human rights violations inflicted on women by non-state actors, such as family and community groups (Saghal 2006). As Merry points out, within this universe, the meaning of VAW has expanded from "male violence against their partners in 
the form of rape, assault and murder" to include "female genital mutilation/cutting/excisions, gender-based violence by police and military forces in armed conflict as well as everyday life, violence against refugee women and asylum seekers, trafficking in sex workers, sexual harassment, forced pregnancy, forced abortion, forced sterilization, female foeticide and infanticide, early and forced marriage, honour killings and widowhood violations" (Merry 2009: 82). And as we will see later, the Afghan EVAW law decreed in 2009 listed many of these acts as violence and added a number of other acts more particular to Afghanistan, which many Afghan women considered a violation of their rights, entitlements, or persons, such as the cursing of a woman or even the denial of an existing familial or marital relationship that would absolve obligations toward a woman. ${ }^{1}$ In other words, the Afghan EVAW law was developed at the intersection of transnational and national registers.

As the global campaign against VAW moved to the center stage of international politics, it also, perhaps unsurprisingly, became entangled in existing global power structures. With the shift from national to global advocacy came a more professionalized, bureaucratic mode of operation, standardized programs and compliance mechanisms, and the arrival of international "VAW experts." In an influential article, Kapur (2002) scrutinizes the political effects of this global VAW discourse, noting that it rose to international prominence through the obfuscation of the power relations positioning Westerners, white women, and feminists differently from ethnic minorities and women in the Global South. It constructed women of the Global South and nonwhite women who are subjected to violence or abuse as victims of their culture and in need of (outside) protection. Kapur argues that this effectively amounts to a kind of gender and cultural essentialism that cannot accommodate the different positions that nonwhite women and women in the Global South inhabit, or take into account the historically specific forms that violence against them assume. It is difficult to think of an example of this more glaring than Afghanistan since 2001. Western claims to "liberate Afghan women" while entangled in the geopolitical interests driving the war on terror, exhibited many of the traits that Kapur warns against. Afghan women were frequently represented as victims in need of outside saving, trapped in a backward state, and suffering what the West knew to be violence and abuse-violence that occurred as part of Islam or Afghan culture.

Examining the employment and effects of such "victimisation rhetoric" (Kapur 2002) is integral to the analysis in this book, but a clarification nonetheless feels necessary. Stating that the book is about "violence against women" does not mean it places itself uncritically into the VAW discourse. I do not assume the existence of a fixed or absolute set of practices that await recognition as violence against women. This would suggest an endpoint of liberation and inevitably place countries along an axis of development or civilization, enabling the kind of global 
hierarchies Kapur draws to our attention. Instead, my aim is to examine competing claims made during a particular historical setting about the nature of certain practices and to examine whether they are regarded as violence or transgressions and, if so, against whom and with what consequences.

But while the book is not an attempt to uncritically reproduce the VAW discourse, it is also not a bid for relativism. I recognize the hierarchies generated by the VAW discourse and also believe that it is neither possible nor desirable to define, once and for all, out of context, and somehow prior to power relations, the exact register of actions that would constitute violence against women. I nevertheless maintain that this insight should not make us blind to the fact that, in a given context, the nonrecognition of certain practices as violence can become a blueprint for impunity and can be a symptom of unequal gender relations. Thus, it is the struggle over the meanings of violence against women in a specific period and context-and their implications for gender and power-that this book explores.

A final clarification. Throughout the book, I use the terms violence against women and gender violence interchangeably when referring to the empirical focus of my research-abuses committed against women. However, I recognize that each term is imprecise. As I have argued, violence against women is a categorization of an event or practice connoting transgression or violation, but it is also an established activist and policy discourse with particular political logics and effects. Gender violence, on the other hand, has come to delimit a field that comprises violence against women plus sexual violence against men. This is problematic in so far as it suggests that only certain forms of violence are gendered, when, in reality, all social practices have gendered dimensions (although some acts and events might have starker gender dimensions than others). In this book I use gender violence to refer to injuries inflicted only on women, but this usage is merely a practical matter-I do not wish to suggest that men cannot be on the receiving end of violence enabled by, or in response to violations of, gender orders.

\section{VIOLENCE AGAINST WOMEN AND BROADER FIELDS OF POWER}

As the discussion has already hinted at, definitions of and negotiations over violence against women are not just entry points to looking at gender relations. They also illuminate other fields of power. As Hajjar points out, struggles over women's rights are also contestations over jurisdiction and authority (2004). Attempts to make gender violence a public issue could signify an important shift in the demarcation between the private domain of family and kinship on one hand and public authorities on the other. For instance, if a rape case is adjudicated in a state court rather than settled between the families involved or by a local leader or kinship group that traditionally settles disputes, this expands (or attempts to expand) the 
domain of the state-whether by conscious political strategy or as an unintended by-product. A large body of literature on the Middle East has, in fact, emphasized how rulers and states have attempted to break up kinship structures and assert state power by, for instance, promulgating family laws (Noelle-Karimi 2002; Joseph 2000; Kandiyoti 1991; Charrad 2001) or by taking over the policing of female sexuality from relatives and communities (Baron 2006). The attempts by successive Afghan rulers to curtail bride-price ${ }^{2}$ and forbid child marriage espoused similar agendas (see chapter 1).

Yet, what exactly does it mean to say that gender violence is transferred from a private or non-state realm to a "state domain"? As legal anthropologists, in particular, have reminded us, state power or "the state" is a tricky concept. Claims to act on behalf of the state should not lead us to assume the actual existence of a monolithic, unitary state (T. Mitchell 1999). And in sites of global intervention like Afghanistan, stark transnational aspects to statehood mean that the notion of the "state" as a unitary actor wielding ultimate sovereign power over a territory makes even less sense. As is clear to even a casual observer of post-2001 Afghanistan, Western powers played a fundamental role in structuring Afghan statehood-to the extent that international actors explicitly tasked themselves with the wholesale building of the Afghan state. With this in mind, it is far from certain that the power exercised in a government court-for instance, if an Afghan man is prosecuted for rape or wife beating - is that of the Afghan state. As I will discuss in some detail in the chapters that follow, the ways in which the Afghan state intervened in cases of gender violence was often underwritten, funded, and even designed by global, mostly Western actors, suggesting that the sovereign power exercised in Afghan courts was partly global. At the same time, the economic and political resources flowing from the international interventions often constituted opportunities for local actors to exercise and consolidate power in ways unintended by the international "state builders."

It makes sense, then, to understand sites of international peace-building interventions as "fields of power where sovereignty is constantly contested and negotiated among global, elite and local actors" (Heathershaw and Lambach 2008: 269). In this vein, challenges to and negations of the nation-state (the sovereign) in (post-)conflict settings are best conceived not as from below or above (that is, from local or global sources), but as parallel or alternative alignments that often are transnationally woven. In order to make sense of the ways the global, the national, and what might be termed the tribal are entangled in Afghanistan, I draw upon Saskia Sassen's concept of assemblages (Sassen 2008: 67; Heathershaw 2011). She argues that thinking in terms of assemblages allows us to appreciate that the global can be "dressed in the clothes of the national" (Sassen 2011). In other words, Sassen underlines how national institutional capabilities are reassembled to serve 
global projects. Rather than an image of national versus supranational sovereignty as a zero-sum game in which globalization means the "withdrawal of the state at the hands of the global system" (Sassen 2008: 65), Sassen advocates thinking in terms of specialized orderings-assemblages that produce a standardized, but partial, global domain through national institutions. As I try to show in this book, this "partialness" of global influence was both a resource for and a constraint to local women's rights activists.

Claims about gender violence can do more than reveal gender relations and sovereign domains. They also constitute maps to broader ideological and political fields. The actors who made the claims and counterclaims about gender violence in Afghanistan articulated rights, entitlements, and obligations with reference to larger political narratives and ideological resources in ways that they thought would resonate with their audiences.

I suggest that these discursive strategies-and to what extent they gained traction-reveal broader fields of power-constituted by established social practices and repertoires of meaning, as well as more temporal political alignments. When, for instance, women in Parliament made careful attempts to boost their defense of the EVAW law by referring to sharia, their strategy revealed not only the enduring prominence of Islamic jurisprudence in the legal landscape of Afghanistan but also the current political dominance of the mujahedin, ${ }^{3}$ whose credentials were closely linked to Afghanistan's foremost identity being an Islamic one. Similarly, the ability of a local journalist to discredit women's shelters by conjuring up images of corrupt and self-serving female activists who invoked the plight of poor women for their own financial benefit reflected an overall disillusion with the international aid industry and a skepticism toward "Westernized" women and their foreign allies, all of it given political force by the experience of a prolonged but ineffective external aid and military presence.

Often, however, the strategy in matters of gender violence was not one pursued by making daring public claims, but by calling in favors, discreet lobbying, and personal connections. Officials at the Afghan Independent Human Rights Commission (AIHRC), having failed to build up domestic human rights constituency that could have been mobilized in individual cases, often chose to develop close relationships with government officials so that they could at least extract certain favors. ${ }^{4}$ Its international ally, the United Nations, often chose similarly discreet tactics. When a high-ranking government official seemed destined to be acquitted of the rape of a young girl who had fled her family and had been under his protection, UN staff chose to make a quiet phone call to the local governor rather than a public appeal for justice. These discursive and tactical maneuvers, and the level of their success, chart the political and ideological landscapes in Afghanistan and show the space that various actors perceived was at their disposal. 


\section{STUDYING POWER THROUGH THE}

"AFGHAN WOMAN"

One of the chief aims of the book is to make a contribution to the field of Afghan gender studies by demonstrating that the study of gender in Afghanistan illuminates central questions pertaining to governance, sovereignty, and power. Perhaps one of the most politicized figures of global affairs in the last two decades, the "Afghan woman" is saturated with connotations. In a series of homogenizing representations, she has been invoked both as a victim whose circumstances necessitated bombing raids and military operations and as a haunting symbol of Western imperialism. ${ }^{5}$ Her circumstances and appearance are constantly noted and made to serve as an indicator of diverse political assertions - the hypocritical hollowness of Western rhetoric, the backwardness of Afghan culture, or Afghanistan's foreign contamination. Funds are raised in her name, and numerous reports are devoted to give her a voice and uncover her true views. Those who can claim this identity have also learned to utilize its potential for mobilizing power. Claiming to speak as an "Afghan woman" to international media outlets can be a shortcut to influence in a setting where most other political channels have been closed off by violence and militarization.

Yet despite the many ways in which the "Afghan woman" has become a purveyor of broader political claims, the scholarly literature on the intersections of gender, power, and politics in Afghanistan is scarce. More recent literature tends to be based on textual examination of Western discourses in which the situation of Afghan women serves to legitimate domination or invasion (Schueller 2011; Stabile 2005; Ayotte and Husain 2005; Abu-Lughod 2002). On the other hand, contributions that elaborate on more localized relations of gender and power typically do so only as a side pursuit and often subscribe to a conceptualization of Afghan society as consisting of separate orders locked into a perpetual struggle over the control of women. For instance: "Rural Afghanistan is the root of tribally powers that have frequently doomed Kabul-based modernization efforts. Social traditionalism and economic underdevelopment of rural Afghanistan have repeatedly contested the center (Kabul), thus a better understanding of tribal controlled areas is essential to empower women in these regions. For women in rural Afghanistan, control over their lives and gender roles is determined by patriarchal kinship arrangements" (Ahmed-Ghosh 2003).

Quotes like this conjure up a spatial map of gender and power in Afghanistan. The central state resides in the capital and urban centers-enclaves of female emancipation-whereas the majority of women are hidden away in the deepest corners of tribalism in faraway villages and forts, kept out of reach by their menfolk and shielded from the grasp of government, modern law, and individualism. There is also an evolutionary dimension to this spatial optic; the gender order of 
the tribe is expected to gradually wither away as it comes into contact with the more modern state. Such notions reflect a tendency in studies of Afghanistan to infer from separate realms (in the sense of boundaries made, and thus in need of constant, active maintenance) the existence of separate, discreet "logics," or in the terminology of Edwards, different "moral systems" (Edwards 1996). ${ }^{6}$ More recent work has slowly started to discard this framework (Coburn 2011; Green 2008; Sharan and Heathershaw 2011; Edwards 2002), instead approaching power and governance as hybrid and contingent on context. However, as the Ahmed-Ghosh quote above shows, notions of self-contained and insulated governance and political orders continue to hold sway in the limited scholarship on gender and politics in Afghanistan (for exceptions, see Kandiyoti 2007; and Billaud 2015).

This book attempts to address this gap by carrying out a study of women and power in Afghanistan that applies an open-ended, practice-oriented perspective through ethnographic examinations on statehood and authority-an approach that has especially been seen in studies on sub-Saharan Africa (Lund 2006; Bertelsen 2009; Comaroff and Comaroff 2006; Comaroff and Comaroff 2009; Hansen and Stepputat 2006; Hagmann and Péclard 2010). This open-ended approach enables me to make transnationally constituted assemblages of rule visible and available for analysis, and it allows me to accommodate complex governance orders that transcend dichotomies of tradition and modernity, or of the global and the local. For instance, the need to go beyond the binary of tradition and modernity is illustrated by the many incidences in this book where ideas of personal or family honor are seen to have affected government processes within the state apparatusas opposed to honor being a tribal value incongruent with modern state governance. Similarly, I go beyond dichotomies of the global versus the local by showing how global templates and agendas did not simply displace local ones but instead created unique and new dynamics in which, for instance, international diplomatic pressure and Afghan personalized politics reinforced each other.

The book also aims to add to the comparative feminist scholarship on women, law, and power, a field in which Afghanistan has received little, if any, systematic consideration. ${ }^{7}$ Rather than taking the field of family law as the starting point, the book centers on criminal law by making definitions of gender violence the topic of inquiry. In this sense, this book is also a contribution to feminist analysis of criminal law, which has been relatively sparse in the area of countries with Islamic legal traditions (Zuhur 2005). ${ }^{8}$ More generally, I have sought to bring the issue of gender in Afghanistan into closer dialogue with the rich literature on gender in the Middle East, which, over the last three decades, has illuminated the great varieties of gender relations and government practices across time and space in Muslimmajority countries, and which has made important points about the imperative of seeing gender relations as historically specific, rather than as derivatives of religion or culture (Abu-Lughod 1998; Meriwether and Tucker 1999; Kandiyoti 
1996; Tucker 2008; Kandiyoti 1991; Keddie and Baron 1991). In addition, a vibrant scholarship on gender justice and the limits of law as a tool of empowerment has emerged from South Asia in recent years (Basu 2015; Agnes and Ghosh 2012; Roychowdhury 2016; Roychowdhury 2015; Vatuk 2013). I apply the insights of this literature to place the efforts against gender violence in Afghanistan in a comparative perspective, again seeking to counter the exceptional status often bestowed on the country in academic discourse.

Finally, this book has also, in many ways, heeded Abu-Lughod's call to explore "the social life of Muslim women's rights" in order to "track carefully, across multiple terrains, the way both practices and talk of rights organize social and political fields, producing organizations, projects, and forms of governing as much as being produced by them" (2010: 32-33).

Given the enormous attention they have been afforded over the last decade, it is not at all surprising that Afghan women's rights have been pressed into the service of international and local agendas of various kinds: war, careers, and the accumulation of aid money, to mention a few. But the relationship between the "Afghan woman" question and practices of power need not always be so obvious or instrumental. In attempts to secure women in Afghanistan protection against gender violence, ambiguous victories, curious alliances, and novel hierarchies often materialized. These more subtle and mostly unspoken dynamics, which Abu-Lughod (2010) calls attention to, form part of the discussion in the book.

\section{RESEARCH TRAJECTORIES}

Afghanistan during the first decade and a half after the fall of Taliban in 2001 was a place of sharp fault lines and cleavages; of constant contest over the criteria through which power, authority, and the control over resources could be claimed; and of much anxiety about carving out a place in the new order. Moral universes, political repertoires, and hierarchies of knowledge and skills were of uncertain validity as old elites and newly assertive groups vied for position. Many Afghans returned from exile, including members of the former ruling classes, royalists, and old business and landowning families who had fled to neighboring countries, as well as Western-based diasporas armed with academic qualifications and bilingual fluency that suddenly were hugely marketable. The returnees were faced with newly powerful military commanders backed up with Western cash and arms and their self-assured young followers-and with an Islamic clergy who had seen their unprecedented influence and prestige under the Taliban government turn to dust with the new post-2001 order (Giustozzi 2008). By the middle of the decade, war was regaining pace. Explosions, assassinations, and raids fractured everyday life, throwing up uncertainty about the daring official declarations of a new beginning and the future shape and direction of the country. As NATO countries 
gradually realized that the country they had invaded in 2001 was sliding off the course they had staked out, their response was basically to accelerate everything. Money, troops, diplomats, and military operations flowed into Afghanistan in spiraling numbers, typically intensifying conflict lines, incentivizing the pillaging of resources, and increasing the devastation of war.

The research for this book started out as a $\mathrm{PhD}$ project. I arrived in Afghanistan for my initial fourteen months of fieldwork in the summer of 2009, in what promised to be a turbulent context for research. Like many of my informants, I would often get the feeling that at any moment, the rug could be pulled from underneath the universe we were inhabiting. It was clear that the country would not be an appropriate setting for bounded ethnography, in which much time is spent developing intimate relationships with a limited group of people in a small locality. Instead, my research would take the form of "mobile ethnography" (Marcus 1995). In pursuit of answers to how gender violence were defined, contested, and regulated in Afghanistan, I intended to trace a range of different cases and processes as they moved from one site to the next: court rooms, Parliament, official meetings and conferences, local councils, shelters, media forums, and a host of other settings.

My decision to draw upon the extended case method as a framework for data collection was partly influenced by my intention to follow processes from site to site. The extended case method, developed by the so-called Manchester school of anthropology, uses a case (a case being defined as an event or a process) as a way of casting light upon a particular society-or, more accurately, upon the social relations that are actualized in a particular context (Gluckman 1965; Velsen 1964; J. C. Mitchell 1956; Handelman 2005; Burawoy 2000). A case is a departure point from which one can "extend out"-bring social relations into view and available for analysis. This method, whose script was to follow events over time from one setting to another, resonated with my approach to use contestations over violence against women as windows into relations of gender, governance, and politics. Moreover, the extended case method provides a lens suitable for capturing the transnational dimensions of local practices. At a time when ethnography was often preoccupied with unearthing the underlying structure of what was assumed to be self-contained local communities, the 1950 s anthropologists who pioneered the extended case method distinguished themselves from their contemporaries by looking at events as both locally and globally constituted. As Burawoy proclaims when explaining how the Manchester school would make global class relations and colonial history integral to their analysis of the practices of Zulu chiefs: “There never was any isolated tribe here!" (Burawoy 2000: 16). The importance of exploring both local and transnational aspects of the events and processes I was studying-whether debates over a new law, controversies over women "running away" from home, or the trajectory of an individual episode of gender violencebecame one of my guiding principles. 
As I began fieldwork in 2009, I started by establishing how cases of gender violence typically encountered the legal system and how they traveled through it. Little in-depth literature on the practices of the Afghan legal system existed, and developments over the previous two decades were particularly hazy. ${ }^{9}$ Through these efforts, I also hoped to be able to eventually identify the cases of gender violence that would serve as the cornerstone of my material. I had thought that U.N. organizations in the human rights field might serve as a useful entry to cases that I could study, but they proved reluctant to discuss concrete episodes. At the time, there were good reasons for this. Much of the human rights community was shaken by the recent murder of Dilawar, the husband of the victim in a high-profile rape case. In a horrifying ordeal, his wife, Sarah, had been sexually abused and made to walk half-naked through her village after questioning a local commander and government ally about the disappearance of her son. Although the perpetrators of the abuse had been convicted, two of them were quickly freed through a presidential pardon. Sarah and Dilawar went to Kabul to pursue the case, and the local office of the U.N. human rights section played an important role in the public outcry that had followed, which had forced President Karzai to review the pardon. But the case took another sinister turn when Dilawar was murdered. The local U.N. human rights section realized they were becoming increasingly marginalized in a political climate where-both internally in the U.N. mission and externally in the country-realpolitik increasingly overrode accountability and legal procedures. In such a situation, it was not surprising that they were reluctant to share information with me.

However, in the summer of 2009, women's rights activists in Kabul and their international colleagues were preoccupied with two new pieces of legislation: the Shia Personal Status Law and the EVAW law. The Shia law, as it was widely called, had created an uproar among many women activists and politicians, as well as among Western embassies and public opinion, when it was ratified by the president in March 2009. Presented as a recognition of the Shia minority's right to adjudicate according to the sect's jurisprudence, the law contained what was widely felt to be an excessive codification of personal life, in many ways representing a rolling back of the rights in the existing Civil Code and certainly reversing the momentum in women's rights since the 2001 invasion. Despite protests both in Afghanistan and abroad, a revised version of the law (with many of its problematic provisions remaining) was signed into force by the president on July 19, 2009. A few days later, this setback was the subject of heated debate at a meeting of Kabulbased women's activists, both Afghan and foreign, that was called in response to the new law, and which I observed.

The discussions and atmosphere at the meeting appeared to reveal a women's movement fractured by diverging discursive reference points, by multiple modes of organizing and ideas about advocacy or lobbying, and by parallel reporting lines 
and constituencies. Most striking was the confusion and uncertainty regarding the legal framework. The participants at the meeting were trying to establish which law took precedence: the Constitution, the existing Civil Code, the newly decreed Shia law, or the EVAW law, which had been signed by the president on the same day. These laws contained contradictory implications for, among other things, restrictions on polygamy and the legal age of marriage. It took me some time to realize that the confusion I witnessed was not due to lack of preparation for the meeting, due to how hastily it had been organized, but it reflected two important aspects of the post-2001 legal reform process: a great opaqueness in the legislative process and contradictions within the rapidly expanding body of law itself.

The EVAW law, which many of the activists pinned their hopes on, enumerated twenty-two crimes as violence against women, stipulated their punishments, and outlined government responsibility (see chapter 2). It was to be introduced for ratification in Parliament that autumn. With my Afghan colleague Orzala Ashraf Nemat, with whom I was working on another project, I attended the initial debates in the Joint Commission meetings in Parliament, where the law was being discussed before being introduced in the plenary. This required considerable effort, and the help and goodwill of many members of Parliament (MPs). Parliamentary debates were generally not transcribed, not even plenary debates, and the proceedings of the Joint Commission were certainly not. In order to be present in Joint Commission discussions, we were dependent on MPs to sign us in as visitors and-equally crucial-to inform us of when and where the meetings would be scheduled. Often, meetings were called at the last minute, as a deliberate strategy to ensure that certain people were there (and that certain others were not). There was always a chance that we could be told to leave the room. MPs had the opportunity to invite guests, and many of them did, but this sometimes led to controversies, when the guests intervened in discussions. Although the parliamentary process for the EVAW law was eventually abandoned, I continued to follow the law by attending various conferences in which it was debated and by tracing how it entered the agenda of the numerous workshops and training courses that made up the extensive network of donor-driven gender activism (Kandiyoti 2009), which was by then fairly institutionalized in the country.

Meanwhile, I found a very useful source of information in a handful of legal aid organizations, whose staff generously shared information about how they worked on incidents of violence against women and the typical trajectories of such casesfrom police investigations through to the courts. They also alerted me to cases they themselves thought were significant or interesting, and I started to follow these up. At this point, I was fortunate to have a research assistant, Mohammad Jawad Shahabi, who was then a student in the Faculty of Law at Kabul University and who would later become a long-term research partner. In pursuit of these individual cases, Jawad and I traveled, certainly not across the country, but to a 
good portion of the provinces that were considered stable enough for us to visit. Two of the cases I eventually decided to include in this book were from Talibancontrolled districts out of reach for the Afghan government as well as for me. Here I sought the help of two local researchers, who carried out some of the interviews. The material they gathered was then crosschecked and supplemented by other interviews, largely by phone, to local government officials, journalists, and others.

Few of the women at the center of the individual cases discussed in chapters 5 and 6 were interviewed. Some of them were dead, and others were imprisoned or had male family members who insisted on speaking on their behalf. It is the stories narrated by those around them, a web of information often contradictory and certainly disputed, that constitutes the material for my analysis in this section of the book. The focus of the interviews was to try to reconstruct particular events retrospectively, to establish what had taken place and what had been said. These accounts of what had happened were narrated by various informants and were therefore shaped by their particular views, but because data was triangulated through the interviewing of multiple informants, it was possible to establish some kind of chronology of events (the sequence of what had happened and what was said when) and to sort out the multiple readings of what had taken place (what was contested and what was generally or universally agreed upon).

From one perspective, the exclusion of the women themselves as informants can be seen as a weakness in the analysis of these cases. On the other hand, it would have been problematic to ask about-and reveal-intimate material from the women themselves in episodes that had already gained widespread publicity. It was also this publicity that generated so many divergent claims and narratives, and which made for a richer material to draw upon for analysis. After a while, I also developed some skepticism about the way in which certain women were offered to me as interview objects. Some shelter staff, for instance, would, on their own initiative, offer visitors, including me, free access to their residents, accompanied by the encouragement: "ask her whatever you want." While making use of some of these "opportunities" might make for captivating stories (A. J. Rubin 2015), it would also raise some questions about consent and voyeuristic writing.

It was a stay in the city of Herat, after some months of fieldwork in Kabul, that alerted me to the maneuverings by women's shelters, a new institution in Afghanistan. The shelters provided temporary accommodation for women who, for various reasons, could not or did not want to live with their families. These shelters were under constant scrutiny for allegedly undermining family and morality by encouraging women to leave their families and husbands. For women to live in a nonfamilial setting-except for arrangements like university dormitories-was generally unheard-of in Afghanistan. The shelters were a radical development. However, because adultery-and, according to some legal interpretations, "running away from home"-was criminalized in Afghanistan, the shelters were not 
only facing the outrage of conservative groups. They were also accused of housing criminals. In Herat, I was informed that, on this basis, women who could not prove that they had not committed adultery (i.e., women who had not come directly from their family homes to the shelters or government authorities-perhaps because they spent one or more nights with more distant relatives or in a hotel) would not be admitted to the shelter in the city. Attempts on my part to find out whether this was a universal policy among the dozen or so shelters across the country led me to probe them further as institutions, which revealed how they operated in a curious transnational space, navigating between international support and local skepticism.

Some months after my initial departure from Afghanistan, a controversy erupted that brought these tensions into sharp relief. The minister of women's affairs declared her intention to put all shelters, currently run by NGOs, under government control and to establish committees at the provincial level to decide whether individual women were qualified to enter the shelters. The NGOs and women's rights activists who ran the shelters protested, outraged by what they saw as government encroachment on their territory, with severe consequences for women's protection. During another visit to Kabul, in the spring of 2011, I retraced this chapter in the ongoing controversy around the shelters. By then, a well-organized campaign carried out by Afghan activists and international supporters had succeeded in reversing the minister's decision, and it appeared as if the shelters would be able to continue their tenuous existence for the time being.

Doing research in "official” Afghanistan was not straightforward. My efforts to contact the Supreme Court in order to obtain statistics on convictions and similar documentation bore little fruit. Sometimes even setting up interviews with judges was a challenge. Then, in 2013, after a research project commissioned by the World Bank had revealed systemic corruption in the courts, the Supreme Court proceeded to ban all Afghan judges from talking to researchers without a written permission from its top officials. Legal documents and rulings were generally not made available to the public and were frequently little more than loose notes in an official's drawer, if they existed at all. It often appeared as if information was a resource to be carefully guarded and to be given away only in a transaction of mutual benefit, whether in the form of other information or promises of future favors. As I sought to speak to specific individuals connected to a particular case or processwhether these individuals were family members, journalists, legal and government officials, aid workers, or politicians, many of whom were very busy-it sometimes took weeks, even months, and long chains of introductions to set up a particular interview. Appointments could be repeatedly cancelled, especially when explosions, attacks, or other security threats temporarily closed down government buildings, led to road closures, or resulted in staff in international organizations being ordered into several days of lock down. A few people declined to meet me 
altogether, such as certain high-ranking government officials like the speaker of Parliament and the chief justice. On the other hand, many people were extremely generous with their time and often agreed to multiple interviews.

Upon completing my PhD, I returned to Afghanistan with regular intervals. Then, in 2014, I embarked upon a two-year stay in Kabul to work on a project funded by the Norwegian Research Council on the prosecution of violence against women. The project was a collaboration between my home institution, the Chr. Michelsen Institute, and the Kabul-based Research Institute for Women, Peace, and Security. Two Afghan researchers and I formed a core team of three. Our task was to produce more precise data on the numbers and types of cases of violence against women exiting the criminal justice system, which we hoped would lead to a better understanding of why so few cases resulted in a criminal conviction. Although my two Afghan colleagues, Mohammad Jawad Shahabi and Farangis Elyassi, did much of the day-to-day data collection, upon which our joint publications are based (Shahabi and Wimpelmann 2015; Shahabi, Wimpelmann, and Elyassi 2016), they have generously allowed me to use some of the material for chapter 3 of this book.

That chapter details the everyday workings of the specialized unit for prosecution of violence against women in Kabul, based on long-term observation in the unit over seven months in 2015. The unit had been set up through donor funds and with the intention of strengthening the implementation of the EVAW law, although its achievement in this regard would prove quite ambiguous. Farangis Elyassi, a recent law graduate, sat for months in the special prosecution units for violence against women in Kabul, among the constant comings and goings of complainants and their families. Most of the time she would be in one of the two investigators' offices, where several groups of complainants, suspects, and witnesses would be interviewed by the prosecutors at any one time. Together we would review her field notes on a weekly and sometimes daily basis, producing a gradual understanding of the workings of the prosecution unit and whether it could be said to be functioning according to its official purpose.

In this period, I also undertook some additional research on the gendered workings of the justice system during two periods about which there is very little documentation: the years of Soviet and Taliban rule. Covering these periods comprehensively would be worthy of several separate book projects. The material I collected by interviewing former judges, prosecutors, and scholars forms part of chapter 1 in the book and amounts to a very modest contribution.

\section{ETHICAL PITFALLS OF RESEARCH IN AFGHANISTAN}

When I started my fieldwork in the summer of 2009, NATO's warfare in Afghanistan was about to reach its most intensive period, and the country occupied a prime 
place in the foreign policy agenda of most Western countries. The Obama administration was coming to terms with the fact that it had inherited a costly and deteriorating war, and it reinvigorated its efforts to "understand" Afghanistan and the conflict. Western media interest in the country was intense, and research reports and commentary were produced in abundance. As a foreign researcher in the midst of - and, to a certain extent, operating on the back of-the Western military operation in Afghanistan, I was also implicated in this knowledge-intervention nexus.

Research in a setting like contemporary Afghanistan, where so many careers have emerged out of a sudden imperial rush to understand, map, and transform the country, can quickly appear exploitative. An obvious aspect of this is that much, if not most, of the scholarly work has been produced by foreign researchers, often with limited linguistic skills and during brief fieldwork. I myself only speak and read Dari with some level of fluency, and I still prefer to use an interpreter for more abstract or technical conversations. Like many of my non-Afghan colleagues, I have relied extensively on Afghan colleagues for translation and for company when traveling outside of Kabul. As more Afghans obtain PhDs-like several of my close colleagues over the years-the relationship between Afghan and non-Afghan researchers might become somewhat more balanced. Yet the disparities of global knowledge production, at the heart of which is unequal access to higher education and funds, look to remain in place for the foreseeable future.

At the same time, like Julie Billaud (2015), I do not see my research as an attempt at representing or giving voice to Afghan women or to provide a definite account of "Afghan reality." That would, indeed, put questions of positionality and the right to speak for "the other" into even sharper relief. Rather, this book is a study of the particular dynamics and contradictions that emerged at the intersections of local and transnational attempts to define and address gender violence, which were situated within a larger context of highly conflictual politics. But as I proceeded with my data collection, a dilemma nonetheless made itself felt. It was between, on the one hand, a position of solidarity to the victims of violence and those working to support them and on the other hand, a more problematizing stance toward the power relations that they were enmeshed in. For instance, when researching and writing about the controversies around the shelters (chapter 4) - and exploring the hierarchies that their constitution as "transnational entities" dependent on Western support entailed-I sometimes felt uneasy about the way I was subjecting them to such critical examination. These were, after all, organizations providing an important service. As this book describes, shelters were often the only place where women fleeing abuse or an unwanted marriage could go. At times, it seemed petty to question their mobilization of Western funds and support when this obviously enabled them to offer shelter to women who had very few options. The uncompromising stand of some of the shelters-enabled by the relative autonomy from the 
government and Afghan society that their external support afforded them-also allowed them to accommodate a wider range of women, including women who might be excluded (as they were considered unworthy of protection) from shelters that were more in line with government policy. Refusing to compromise and pushing the boundaries of female propriety is an act of feminism, at least at face value. Should I not place myself squarely in solidarity with such a position?

Pointing out the trade-offs and shortcuts involved in the EVAW law accentuated similar ethical dilemmas. The EVAW law, as chapter 2 details, was promulgated and implemented in ways that were largely dependent on Western pressure and funds and that undermined the parliamentary process. The law was also technically flawed; in places it contradicted the rest of the legal framework, and it contained unclear legal terminology that would make it difficult for judges to implement it. Yet, as some women passionately argued, the EVAW law was a big achievement in many ways. Indeed, one high-level official in the Ministry of Women's Affairs told me directly to "leave the EVAW law alone" and avoid drawing attention to the questions around its legal status - or even to the law's existence. (The law had not been ratified by Parliament, and some of the law's supporters felt that conservative MPs would never approve it anyway, so the best strategy would be to discretely withdraw the law from Parliament in order to avoid its explicit repeal.)

Both cases brought to the forefront the tension between examining gender violence and scrutinizing the broader power relations that activists, shelter managers, and others operated within. I did not want to belittle the gender violence in Afghanistan-or the sense of urgency and outrage that activists were trying to generate around it. But at the same time, I thought it important to problematize the choices and compromises made by the women's rights advocates and the local and global power relations produced and maintained as a result. Of course, the latter can be a productive exercise also for activists-in the sense of engaging in reflective praxis. But I was not a fellow activist. I did not have a background as a feminist activist anywhere, certainly not in Afghanistan. I was a foreign researcher. In fact, I arrived to the field unprepared for the politics of feminism; I had not engaged much in conscious thinking about the different coalitions, imaginaries, and tactics that feminists employ-and disagree over-in the pursuit of women's rights. Instead, the main fault line that I expected to encounter was between feminists and their adversaries - those who sought to define gender violence in ways that reinforced patriarchal privileges or to explain it as a regrettable part of Afghan "culture." I had not given much thought to the more internal dilemmas of feminist political praxis: the tensions between the immediate and the long run, between making broader coalitions or seizing the moment, even if it meant forming uncomfortable alliances. But it was these questions around political strategy that increasingly would come to occupy my thoughts. 
I found myself agonizing over an emerging conviction that real feminist gains could only be anchored in democratic political relations, but, at the same time, I could not see much possibility of this happening in Afghanistan. And at times I saw little interest among women in broader political mobilization or gaining independence from external support. For many of my female informants, the important thing was to get the infrastructure in place that could ensure women a measure of protection from violence-and to do it immediately-even if this meant relying on Western pressure and funds. They sometimes pointed to the difficulties of more directly confronting the conservatives in their country, who commanded significant power of intimidation. Although political violence against women was not all that widespread compared to settings such as U.S.-occupied Iraq, outspoken women always risked being labeled immoral or worse, which could cost them the support of their families and make them feel insecure.

To me-a citizen of a country where weighing your physical security against outspokenness and assertiveness was fairly inconceivable-taking a more critical approach to the strategies that the activists were using to further their goals sometimes felt like an exercise in academic indulgence. Up to a point, I have sought to resolve the dilemma I experienced between apolitical-ethical commitment and critical analysis by striving to be empathetic in my critique. As I elaborate in the conclusion, I cannot see any easy choices or infallible positions in the struggles that I write about. I have experienced for myself in Afghanistan how quickly and easily fear can make you conform. I recall how-especially during the first months of my research-my own anxiety was sometimes set in motion just by walking by myself for short stretches in Kabul, and how my main strategy for overcoming this was to dress modestly and sometimes (often quite subconsciously) to adopt a posture of feminine deference when walking around, so as to signal respectability and conformance.

My own feelings of insecurity were, of course, rooted in a different kind of positionality than that of my Afghan informants. It was generated by my formal identity as a war-waging Westerner, a kind of occupiers' or colonial paranoia, fuelled by rumors of kidnappings and attack plots. My endeavors to make myself as inconspicuous as possible by dressing modestly and acting discreetly was, in fact, mostly an attempt to set myself aside from the bad Westerners rather than from bad women. My point here is that the courage I sometimes needed to sum up to overcome such everyday apprehensions was miniscule compared to the fearlessness that many Afghans displayed when engaging in politics, travel, or just daily life. Therefore, if this book is to engage in critical analysis of Afghan feminist politics, then it must do so with the acknowledgment that in contemporary Afghanistan, the actors involved (and perhaps the author as well) were faced with a number of difficult dilemmas. No infallible choice was available-all options contained flaws of one kind or another. 


\section{ORGANIZATION OF THE BOOK}

The main body of the book is divided into three parts, each consisting of two chapters. The first part, "Legal Regimes," examines the historical and contemporary struggles over laws and legal regimes governing gender violence. It analyzes contestations over the substance and processes through which laws regulating gender violence were promoted, and the political projects in which these efforts were entangled.

Chapter 1 traces past attempts to achieve closer public regulation of sexuality and of abuses committed within the family and how these attempts were shaped by larger political agendas. It briefly introduces the reader to the first reforms, made by Afghan kings in the late nineteenth and early twentieth centuries. The chapter then draws upon interviews with former leaders, judges, and other officials to provide an account of how the issue of gender has been addressed in Afghanistan's more recent history, especially during the communist (1978-92) and Taliban (1996-2001) eras. In the final part of the chapter, I dissect the contemporary legal landscape. I show how its fragmentary nature can be traced back to the multiple intersections of politics, justice, and gender of the past, while at the same time being a product of the political settlement of the post-2001 order.

Chapter 2 focuses on the law that would take center stage in gender politics in contemporary Afghanistan: the Elimination of Violence against Women law (EVAW law), decreed in the summer of 2009. The chapter explores the origins of the law, the tactics used to promote it, and the opposition it encountered in Parliament. Drawing upon several hundred interviews, observations of parliamentary sessions, activists' meetings, and other fora, as well as unpublished legal drafts and written correspondence, it shows how the EVAW law was promoted through a transnational coalition in which global gender expertise and institutions intersected with personalized and patrimonial local politics. The chapter shows how the partial status the law achieved-signed as presidential decree but never approved in Parliament-reflected the constant tension between three key aspects of the post-2001 order: foreign military operations, the rehabilitation of the mujahedin, and external attempts to promote Afghan women's rights. Supporters of the law nonetheless mobilized a massive apparatus to see it implemented. As the next chapter of the book shows, however, the impact was limited.

The second part of the book, "New Protection Mechanisms," examines how the novel protection infrastructure operated in practice, with a focus on the specialized prosecution units for violence against women and the women's shelters. The analysis explores the type of alliances their supporters entered into, what kind of protection they could offer as a result, and to what extent these institutions challenged predominant gender relations. 
Chapter 3 describes how the specialized prosecution units were initially set up, with donor support, in the hope that they would prioritize cases of violence against women. Drawing upon a wealth of observational data, the chapter documents the everyday working of the prosecution unit in Kabul. It argues that, by and large, the unit did not function as donors intended. Many cases were closed prior to trial, sometimes because prosecutors were reluctant to pursue them, but sometimes because the victims or their families had other agendas altogether. Prosecutors, women, and their families bargained within a paradigm of gender norms in which women's rehabilitation into the family unit and restoring sexual transgressions into the framework of marriage transactions were key reference points. In these cases, the special unit served to reaffirm the notion that acts of gender violence were family problems-not criminal cases belonging in the formal justice system. I suggest that this was a predictable outcome, given how the special prosecution units operated at the intersection of donor pressure, government indifference, and a lack of attention to (or disinterest in destabilizing) broader social relations that cast women's existence outside of the family setting as deeply subversive.

Chapter 4 investigates a series of public controversies over women's shelters. The shelters, by opening up a space where conventional forms of social regulation of women's conduct could not reach, were seen as undermining family control over female sexuality. They encountered and sometimes collided with government practices that upheld family claims over women, such as the practice of detaining women who had "escaped from the house." Eventually, amid a growing populist backlash that depicted the NGO-run shelters as part of a Western plot against family, religion, and morality, the Afghan government made a bid to nationalize them. I argue that the shelters provide a stark example of how women served, on the one hand, as a marker for national sovereignty and religious purity and, on the other, as a litmus test of Western commitments to Afghan women. As Western acquiescence to the proposed nationalization of the shelters was equated with capitulating to the Taliban, the shelter issue was made into a question of military resolve, mobilizing an international outcry that eventually led the Afghan government to back down. Yet international support was a double-edged sword; it exposed the vulnerability of shelters as transnational entities. Western support gave the shelters considerable room to maneuver but, at the same time, left them with limited local anchorage and vulnerable to shifts in Western priorities.

The final part of the book, "Individual Cases," explores the complex avenues of intervention and protection in Afghanistan through the trajectories of individual cases of gender violence. I probe the fault lines revealed in these episodes by asking: What exactly was acknowledged as violations or transgressions? Just as importantly, what was not? How did public institutions of various kinds become involved in dealing with these incidents? The answers to these questions reveal whether 
gender violence has increasingly become a public issue in Afghanistan-and, if so, in what ways and with what consequences.

Chapter 5 details the stories of three women inhabiting the contested position that had implicated the shelters in so much controversy-that of the "runaway" woman. All the women discussed in this chapter had fled their families and the abuse inflicted on them. Based on more than hundred interviews with family and community members, local officials, journalists, and aid workers, the chapter traces the women's fates and the many actors seeking to intervene in their cases. The chapter documents how justice institutions often became mechanisms for reinforcing kinship control over female sexuality but in tenuous ways, forged out of contingent struggles and alliances. The stories of the three runaways show how difficult it was for individual women to escape family abuse in a setting where female subversion of family control featured as a principal transgression. Even if it was possible for some women to receive a sympathetic hearing in a government court, the paths they had to take to escape from abusive situations typically involved difficult choices that left them irrevocably tainted in the eyes of their communities and the law itself.

Chapter 6 examines how the justice system dealt with cases of rape. Specifically, it looks at what appeared to be an unprecedented willingness by families to take rape cases to court, inquiring whether this meant a redrawing of relations of gender and governance in Afghanistan, a redrawing brought upon a reluctant government by mobilization from "below." By examining a handful of highly publicized cases of rape-which were widely regarded as momentous in the way that they generated public demands for government action-I ask whether the new "openness" surrounding rape in Afghanistan signaled a changed position for women. Would rape mean a violation of women's bodily integrity-as opposed to an affront to their male relatives' honor? I further ask whether we can gauge from these cases the contours of a stronger Afghan state. My answer to both questions is a qualified no. The chapter argues that the public claims in these cases were articulated within "stable categories of gender" and sometimes directly as infringements of male honor. Moreover, through a detailed discussion of the aftermath of a rape case from northern Afghanistan, I show that the demands that the state punish the rapists were not necessarily a call for a stronger government role in regulating sexual violence. By situating the case in local and national power struggles, I demonstrate how discourses of affronted honor can instead function as a vocabulary in struggles over access to state power, and in this case, in fact, they were implicated in an attempt to alter the distribution of political power at the local level. 